\title{
BIOMECHANICAL ASPECT OF FELINE DENTAL RESORPTIVE LESIONS FORMATION
}

\author{
ŽIVKOVIĆ R*, MILIĆ LEMIĆ ALEKSANDRA*, TIHAČEK ŠOJIĆ LJILJANA* and ILIĆ J**
}

*University of Belgrade, School of Dentistry, Clinic for Prosthetic Dentistry, Serbia University of Belgrade, School of Dentistry, Clinic for Conservative Dentistry and Endodontics, Serbia

$$
\text { (Received 19th November 2009) }
$$

Feline dental resorptive lesions affect more than one third of all adult domestic cats and continue to be an enigma in the veterinary dental science although different theories about the pathogenesis of these lesions have been proposed. Recently, a hypothesis was introduced that local mechanical trauma could be an important factor in the initiation of feline dental resorptive lesions and that there is a correlation between the occurrence of resorptive lesions and occlusal trauma in cats.

The aim of this study was to analyse stress distribution in feline tooth during occlusal loading in order to accept or reject the hypothesis that dental resorptive lesions in cats might be caused by occlusal trauma.

A solid model of feline tooth had to be created in order to perform the investigation. The idea was to gain data for tooth displacement (deformation) and stress and strain distribution under loading generally for any feline tooth using the finite element method.

The results of the study contribute to the theory that occlusal overload might be one of the causes in multifactorial resorptive lesions in cats. Succession of tensile and compressive stresses and tooth displacement during occlusal loading might be a contributive factor in the pathogenesis of feline resorptive lesions. However, further research is required to confirm this statement.

Kew words: feline dental resorptive lesions, occlusal stress

\section{INTRODUCTION}

Feline dental resorptive lesions affect more than one third of all adult domestic cats. (Van Wessum et al., 1992; Lund et al., 1998; Lommer and Verstraete, 2000; Ingham et al., 2001). Different terms describing the clinical situation were used in literature, including cervical neck lesions, cervical line lesions, feline odontoclastic resorptive lesions, feline dental resorptive lesions. (Wiggs and Lobprise, 1997; Trevor Burke et al. 2000; Harvey et al., 2004). Feline dental resorptive lesions $(\mathrm{RL})$ are concavities in the structure of the tooth most commonly found at the cemento-enamel junction (Trevor Burke et al., 2000). The 
lesions are noncarious, and in $90 \%$ are found in the labial/buccal aspect of the tooth. The mostly affected teeth are mandibular third premolar, maxillary second premolar, mandibular first molar (Wiggs and Lobprise, 1997; Reiter and Mendoza, 2002). Harvey et al. (2004) reported that the mandibular first molar is most commonly affected, followed by maxillary and mandibular canines and mandibular third premolar. The same authors excluded maxillary premolars and molars from their study due to encountered difficulties in identifying RL because of greater differences in radiographic obliquities of these teeth compared to mandibular ones.

Two types of lesions are identified in the literature. Type I lesions or primary lesions are associated with periodontal disease and little alteration in root radio density (Roux et al., 2005). Type II lesions or secondary are more common, frequently are found in the domestic cat especially of older age and are characterized by marginal gingivitis (Harvey et al., 2004; Roux et al., 2005).

Feline dental resorptive lesions continue to be an enigma in the veterinary dental science although different theories about the pathogenesis of these lesions have been proposed. Okuda and Harvey (1992) introduced a hypothesis that local mechanical trauma could be an important factor in the initiation of feline dental resorptive lesions. Later on Trevor Burke et al. (2000) also suggested that there may be a link between the occurrence of resorptive lesions and occlusal trauma in cats. Also, it is interesting to note that restoration of these lesions in cats with glass-ionommers was considered inappropriate (Lyon, 1992). The reported failure rate of these restorations was of $65 \%$ over six months for any one restoration at one site.

The aim of this study was to analyse stress distribution in feline tooth during occlusal loading in order to accept or reject the hypothesis that dental resorptive lesions in cats might be caused by occlusal trauma.

\section{MATERIALS AND METHODS}

\section{Experimental model}

The problem of biomechanical behavior of a complex structure with irregular geometry such is a tooth could be analyzed using the finite element method (FEM). In order to perform the FEM study one is obliged to create a digital model of a structure under investigation. For this study a solid model of a feline tooth was created in order to perform the investigation. Dimensions and morphology characteristics of a feline tooth were gained from the available dental veterinary literature (Harvey, 2002; Gioso and Carvalho, 2005). The basic idea was to gain data for tooth displacement (deformation) and stress and strain distribution under loading generally for any feline tooth. That is the reason why the created model in this paper does not represent any specific tooth morphology, especially due to insufficient data about feline tooth morphology. The model was created in CATIA software. Morphologic details and dimensions were used to define a series of planes at different levels with the outlines of the tooth crosssection at each level. The basic morphology outlines were reconstructed, with the aim to respect crown - root portion relations to each other. All materials that 
Acta Veterinaria (Beograd), Vol. 60, No. 2-3, 303-311, 2010.

Zivković R et al.: Biomechanical aspect of feline

dental resorptive lesions formation

compose animal tooth were considered isotropic and homogenous and were assigned adequate physical properties values according to literature data (Table 1).

Table 1. Physical values for the materials used in this study, Biomaterials properties database, (1996)

\begin{tabular}{|l|c|c|}
\hline & $\begin{array}{c}\text { Elastic modulus } \\
\text { Young's modulus }\end{array}$ & Poisson's ratio \\
\hline \hline Enamel & $84.1 \mathrm{GPa}$ & 0.33 \\
\hline Dentin / Cement & $14.7 \mathrm{GPa}$ & 0.31 \\
\hline
\end{tabular}

The dental pulp was modelled as a void, because pulp accepts very little of the load (Rubin et al., 1983). The biomechanical characteristic of cement was assigned same as dentin, due to their similar biomechanical characteristics.

The boundary conditions were defined as the model and was assumed fixed $2 \mathrm{~mm}$ apical from the cemento-enamel junction, representing the normal coronal level of the alveolar bone. Therefore the influence of soft tissues on stress and strain distribution was not incorporated in this study.

Computer simulation

Simulated loading in the study was definied in two ways. First simulated loading was definied as $250 \mathrm{~N}$ axial (vertical) force acting on occlusal surface of the model. The other was also $250 \mathrm{~N}$ force intensity acting nonaxially, representing the lateral forces acting on a tooth. The finite element mesh for the model was created in NASTRAN program (pre-processing phase), where all later procedures (processing and post-processing) were performed afterwards. The final model with generated finite mesh was presented in Figure 1.

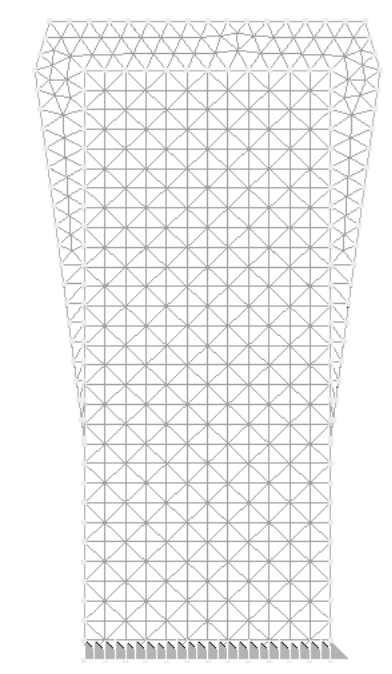

Figure 1. Final FE model of any feline intact tooth with defined boundary conditions and generated finite element mesh

\section{RESULTS}

Based on assumptions involved in the study with the fact that computer simulations were simplified, the results of the study might differ from the values of stresses encountered by teeth in real situations. Therefore, the results were presented and considered qualitatively, not quantitatively, in order to offer more insight in the general situation of feline tooth behavior after loading. 
Total displacement (translation) was evaluated for two different loading conditions.

Total displacement of the intact tooth after occlusal axial loading is shown in Figure $2 \mathrm{a}$ and $2 \mathrm{~b}$. The greatest displacement values are recorded at the occlusal surface, due to tooth structure deformation encountered as a result of loading. Obviously, great deformation happens in the very place where load is applied and therefore the greatest displacement values are observed there. Moving away from the loading point along the long axis of the tooth in apical direction the displacement decreases. This is probbably the mechanism for occlusal load amortization within the intact tooth structure. Certainly it has to be mentioned that such findings are partly recognised as a consequence of the applied boundary conditions.

a)

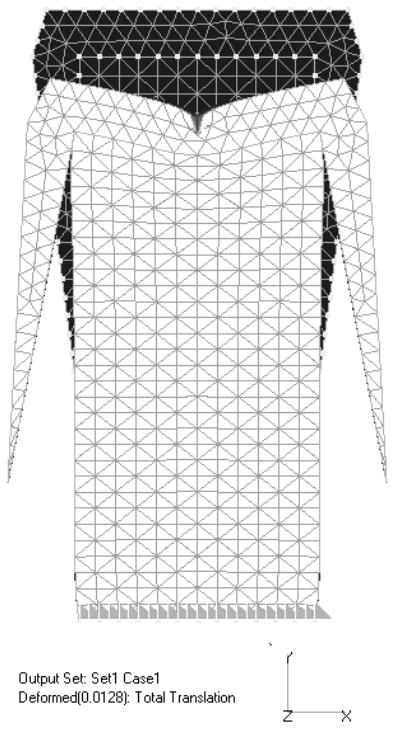

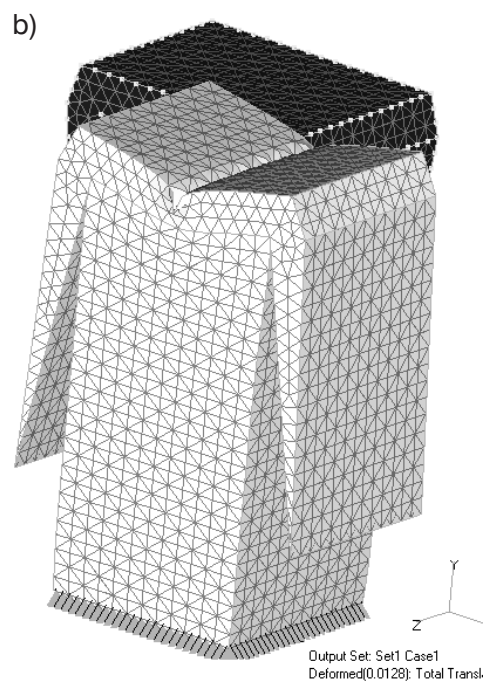

Figure $2 \mathrm{a}$ and $2 \mathrm{~b}$. Total displacement of tooth model after axial (vertical) loading

The stress value was found to be highest at the occlusal portion of the tooth. Concentration of stresses was greatest at the location of loading. Stresses rapidly decreased in the occluso-gingival direction. Close to the cemento-enamel junction (CEJ) the stresses again increased and became concentrated at that location. The pattern of stress distribution through the rest of the tooth structure showed reasonably symmetrical distribution with the exception of occlusal surface and the location close to the CEJ.

Total displacement of the intact tooth after occlusal non-axial loading is shown in Figure $3 \mathrm{a}$ and $3 \mathrm{~b}$. It is interesting to note that most of the great displacement values are recorded at the occlusal surface also. Nevertheless, displacement (total translation) is not uniform as it is when axial force was 
simulated. In this case it is obvious that the whole tooth structure is bending toward the side where the lateral force was acting. As a result of tooth bending different stress distribution was found. Compressive stress values were highest at the place of force acting on the oclusal surface of the tooth, decreasing in values moving away from the location of the loading. But close to the cemento-enamel junction (CEJ), stress values showed a rapid increase. In this case of non-axial loading at the CEJ, compressive stress is dominant on the side toward tooth bending, while on the other side tensile stress showed maximal values.

a)

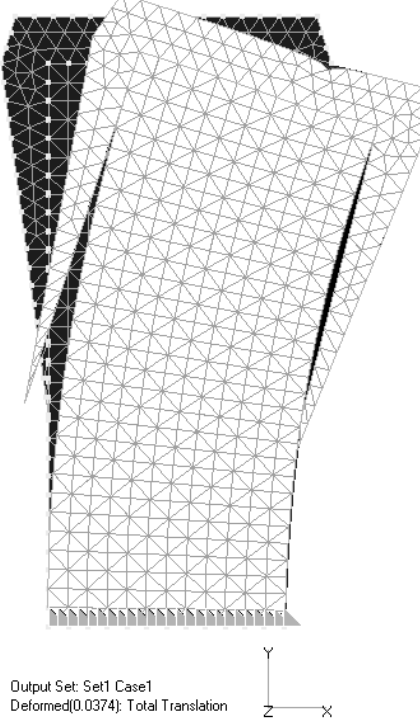

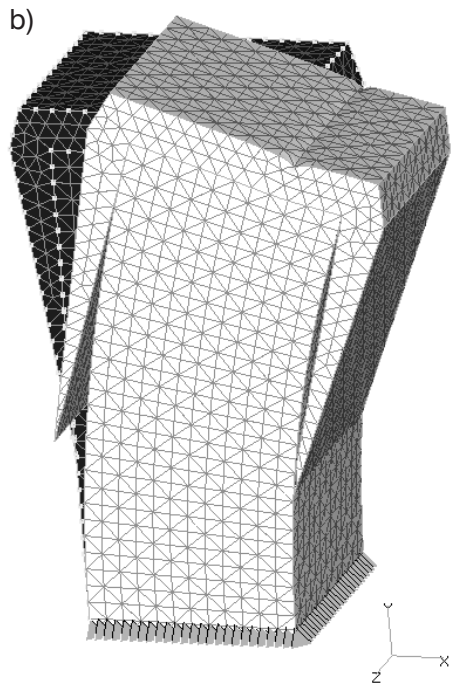

Figure $3 a$ and $3 b$. Total displacement of tooth model after non-axial (lateral) loading

\section{DISCUSSION}

Stress distribution within the intact tooth showed that the severity of stresses are near the CEJ, in addition to the area immediately beneath the applied load. These findings are consistent with reports regarding stress analyses of an intact (unrestored) tooth (Yettram et al., 1976; Khera et al., 1988). Characteristic stress distribution throughout an intact tooth under loading is a result of great difference in mechanical properties of enamel and dentin, two constitutive materials of tooth structure. Enamel is a rigid material and therefore is not deformable, while dentin behave as a resilient material with great deformation capability. Under occlusal loading a sound tooth distributes the high stresses more homogenously, the rigid enamel does not deform significantly but transfers the deformation to the lower more resilient dentin, and thus rigidly move over it (Yettram et al., 1976; Ausiello et al., 2002; Lemic et al., 2006). This is the reason why an intact tooth exhibits overall 
a higher stress values comparing to the restored tooth (Ausiello et al., 2001; Lin et al., 2001; Arola et al., 2001). From the biomechanical point this is probably the mechanism for transfering occlusal forces to a tooth and its surrounding tissues. If a tooth is consisted only of rigid enamel occlusal loading would be completely transfered to the surrounding bone. On the contrary, if a tooth is only made of a soft material such as dentin great deformation would be manifested at the load location with possible rapid wear of the tooth material.

The difference in stress concentration when masticatory forces are acting lateraly can be attributed to basic mechanical principle of leverage saying that forces concentrate at or near the fulcrum. When subjected to lateral loading, tooth with its root acts as a simple lever that fulcrums near the cervical region. As a result of that phenomenon, significant lateral force create tension on one side and compression on the opposite side of equal magnitude. Well known fact is that tooth structure is better designed to withstand compressive forces. Consequently, tooth structure is far more likely to suffer damage when subjected to a tensile force of comparable intensity.

This findings are important in humans because lateral forces are encountered in situations like occlusal disharmony, malocclusions or parafunctional movements. However, such findings may be applicable to veterinary dentistry as stated by Tihacek et al. (2007), since lateral forces can occur during abnormal chewing or biting behavior. As contribution to this statement are also study results of Brech et al. (1997), who said that canine teeth fractures in military dogs most often occured during attack exercises. Gracis and Orsini (1998), stated similarly that dental traumas in cats and dogs are a consequence of fight with other animals, and chewing on hard materials such as bones or rocks. Although von Arx et al. (2009) theorized that feline odontoclastic resorptive lesions are associated with feline viruses, the biomechanical aspect in etiology of these lesions may also be considered. Specific biomechanical response of feline teeth to occlusal loading is moreover confirmed in morphological studies of DeLaurier et al. (2009) who found that enamel is significantly thinner at the cemento-enamel junction, and both enamel and dentine are significantly less mineralized than elsewhere on the tooth. The authors imply that cemento-enamel junction is predisposed to resorptive lesions,

Trevor Burke et al. (2000) have theorized that a possibility for feline resorptive lesions lie in chronic occlusal trauma from present-day feline eating habits. According to same authors resorptive lesions are more frequent findings in domestic cats, which eat a much harder diet, consisting of pellets, rather than the traditional tins of soft cat food.

The results of this study also support the theory that occlusal overload leads to chipping away of dental hard tissues when subjected to subsequent compression/tension stress. Roux et al. (2005) observed an asymmetry in dental cement thickness in feline subjects with dental resorptive lesions. These initial micro fractures of dental hard tissues might lead to progression of the lesions in the feline population, with other etiological factors involved. Micro fractures are also the cause of disturbances of the smooth interface between the cement and periodontal ligament. But excessive occlusal forces might also cause damage to 
periodontal ligaments as a result of tooth bending from one side to another. Alternate succession of tensile and compressive stresses leads to focal ischemia, biochemical alterations and subsequent resorptions. Recent studies of Muzylak et al. $(2006,2007)$ revealed that hypoxic conditions ans local hypoxia in the tooth environment may play a role in the pathogenesis of feline dental resorptive lesions. Harvey et al. (2004) also speculated that either event, tearing of the periodontal ligament collagen fibers or exposing the rough cellular pre-cementum as a result of cement microcracs could stimulate a local microscopic concentration of cytokines. Subsequently, elevation in cytokines concentration attracts stem cells and initiates the resorptive process. Similarly was stated by Trevor Burke et al. (2000) that chipping of enamel prism at the cervical region of teeth and inflammatory changes in the periodontal region initiate resorption of the cervical aspect of teeth in cats.

Although the analysis in this study was simplified, and a lot of assumptions were involved, the results ascribe occlusal overload to be a cause for resorptive lesions in cats. Succession of tensile and compressive stresses and tooth displacement during occlusal loading might be a contributive factor in the pathogenesis of feline resorptive lesions. However, to establish the relationship between biomechanical behavior of affected feline teeth with the origin and progression of resorptive lesions further investigation is required. Also, for a detailed and qualified FE study more precise information are needed regarding feline tooth morphology, physical properties of feline dental material characteristics and occlusal force intensity values.

Accepting the occlusal trauma and tooth bending as a contributing factor it is worth to notice that the material of choice for restoration of feline dental resorptive lesions might be flowable composite resin. With its elastic properties flowable composite flexes with tooth as it bends from one side to another during mastication.

Address for correspondence:

Ass. Mr sci Aleksandra Milić Lemić

Clinic for Prosthetic Dentistry

School of Dentistry, University of Belgrade

Rankeova 4

11000 Belgrade, Sebia

E-mail: saskam@eunet.rs

\section{REFERENCE}

1. Arola D, Galles LA, Sarubin MF, 2001, A comparasion of the mechanical behavior of posterior teeth with amalgam and composite MOD restorations, J Dent 29, 63-73.

2. Ausiello P, Apicella A, Davidson CL, Rengo S, 2001, 3D finite element analysie of cusp movements in a human upper premolar, restored with adhesive resin-bonded composites, J Biomech, 34, 1269-77.

3. Ausiello P, Apicella A, Davidson CL, 2002, Effect of adhesive layer properties on stress distribution in composite restorations - a 3D finite element analysis, Dent Mater, 18, 295-303.

4. Biomaterials Properties Database, University of Michigan Quintessence Publishing, 1996, http://www.lib.umich.edu/libhome/Dentistry.lib/Dental_tables.html 
5. Brech CL, Hamel L, Le Nihouannen JC, Daculsi G, 1997, Epidemiological study of canine teeth fractures in military dogs, $J$ Vet Dent, 14, 2, 51-5.

6. DeLaurier A, Boyde A, Jackson B, Horton MA, Price JS, 2009, Identifying early osteoclastic resorptive lesions in feline teeth: a model for understanding the origin of multiple idiopathic root resorption, J Periodont Res, 44, 248-57.

7.Gioso MA, Carvalho VG, 2005, Oral anatomy of the dog and cat in veterinary dentistry practice, Vet Clin North Am Small Anim Pract, 35, 4, 763-80.

8.ĐGracis $M$, Orsini $P$, 1998, Treatment of traumatic dental displacement in dogs: six cases of lateral luxation, $J$ Vet Dent, 15, 2, 65-72.

9. Harvey CE, 2002, Shape and size of teeth of dogs and cats-relevance to studies of plaque and calculus accumulation, $J$ Vet Dent, 19, 4, 186-95.

10. Harvey CE, Orsini P, McLahan C, Schuster C, 2004, Mapping of the radiographic central point of feline dental resorptive lesions, $J$ Vet Dent, 21, 1, 18-21.

11. Ingham KE, Gorrel $C$ et al., 2001, Prevalence of odontoclasitc resorptive lesions in a population of clinically healthy cats, $J$ Small Anim Pract, 42, 439-43.

12. Khera SC, Goel VK, Chen RCS, Gurusami SA, 1988, A three-dimensional finite element model, Operative Dentistry, 13, 128-37.

13. Lemić A, Tihaček Šojic Lj, llić J, Živkovic $R, 2006$, Computational modeling of specific biological structures behavior, Acta Veterinaria, 56, 4, 367-74.

14. Lin C-Li, Chang CH, Wang CH, Ko CC, 2001, Multifactorial analyis of an MOD restored human premoalr using auto-mesh finite element approach, J Oral Rehabil, 28, 576-85.

15. Lommer MJ, Verstraete FJM, 2000, Prevalence of odontoclastic resorptive lesions and periapical radiographic lucencies in cats: 265 cases (1995-1998), J Am Vet Med Assoc, 217, 1866-9.

16. Lund EM, Bohacek LK et al., 1998, Prevalence and risk factors for odontoclastic resorptive lesions in cats, J Am Vet Med Assoc, 21, 392-5.

17. Lyon K, 1992, Subgingival odontoclastic resorptive lesions: Classification, treatment and results in 58 cats, Addendum to Proceedings to the $6^{\text {th }}$ Annual veterinary Dental Forum, Las Vegas 1-3.

18. Muzylak M, Price JS, Horton MA, 2006, Hypoxia induces giant osteoclast formation and extensive bone resorption in the cat, Calcif Tissue Int, 79, 169-77.

19. Muzylak M, Arnett TR, Price JS, Horton MA, 2007, The in vitro effect of $\mathrm{pH}$ on osteoclasts and bone resorption in the cat: implications for the pathogenesis of FORL, J Cell Physiol, 213, 144-50.

20. Okuda A, Harvey CE, 1992, Etiopathogenesis of feline dental resorptive lesions, Vet Clin North Am Small Anim Pract, 22, 1385-404.

21. Reiter AM, Mendoza KA, 2002, Feline odontoclastic resorptive lesions: An unsolved enigma in veterinary dentistry, Vet Clin North Am Small Anim Pract, 32, 791-837.

22. Roux P, Berger $M$ et al., 2005, Observations of the periodontal ligament and cementum in cats with dental resorptive lesions, $J$ Vet Dent, 22, 2, 74-85.

23. Rubin C, Krishnamurthy N, Capilouto $E, Y i H, 1983$, Stress Analysis of the human tooth using a three-dimensional finite element model, $J$ Dent Res, 62, 2, 82-6.

24. Tihaček Šojic Lj, Milić A, Živkovic R, llić J, 2007, Anatomically based 3D geometric modeling of specific biological structures, Acta veterinaria, 57, 4, 381-90.

25. Trevor Burke FJ, Johnston N, Wiggs B, Hall AF 2000, An alternative hypothesis from veterinary science for the pathogenesis of noncarious cervical lesions, Quintessence Int, 3, 7, 475-82.

26. VanWessum R, Harvey CE, Hennet $P$, 1992, Feline dental resorptive lesions: Prevalence patterns, Vet Clin North Am Small Anim Pract, 22, 1405-16.

27. Von Arx T, Schawalder P, Ackermann M et al., 2009, Human and feline invasive cervical resorptions: The missing link? - Presentation of four cases, J Endodont, 35, 6, 904-13.

28. Wiggs RB, Lobprise HB, 1997, Principles and practise, In: Veterinary Dentistry. New York: Lippincott-Raven, 487-96.

29. Yettram AL, Wright KWJ, Pickard HM, 1976, Finite element stress analysis of the crowns of normal and restored teeth, $J$ Dent Res, 55, 6, 1004-11. 
Zivković R et al.: Biomechanical aspect of feline

dental resorptive lesions formation

\section{BIOMEHANIČKI ASPEKT NASTAJANJA DENTALNIH RESORPTIVNIH LEZIJA U MAČAKA}

\section{ŽIVKOVIĆ R, MILIĆ LEMIĆ ALEKSANDRA, TIHAČEK ŠOJIĆ LJILJANA i ILIĆ J}

\section{SADRŽAJ}

Dentalne resorptivne lezije kod mačaka su vrlo čest nalaz, i mogu se uočiti u više od jedne trećine domaćih mačaka. One su i dalje enigma u veterinarskoj stomatologiji iako je do sada postavljeno mnogo teorija o njihovom nastanku. Nedavno je predložena hipoteza da je lokalna mehanička trauma veoma značajan faktor u inicijaciji dentalnih resorptivnih lezija u mačaka i da postoji veza između nastajanja lezija i postojanja okluzalne traume.

Cilj ove studije je da se analizira distribucija napona i deformacija unutar bilo kog zuba mačke tokom okluzalnog opterećenja, kako bi se potvrdila ili odbacila hipoteza da je okluzalna trauma mogući etiološki faktor u nastajanju dentalnih resorptivnih lezija u mačaka.

Za sprovođenje ovog istraživanja bilo je potrebno krerirati matematički model bilo kog zuba mačke. Osnovna ideja je bila analizirati distribuciju napona i pomeranja tokom okluzalnog opterećenja pomoću metode konačnih elemenata.

Rezutlati ove studije daju doprinos teoriji da okluzalno preopterećenje može biti etiološki faktor nastanja dentalnih resorptivnih lezija u mačaka. Naizmenično smenjivanje zateznog i kompresionog napona u strukturama zuba tokom mastikacije može imati uticaja u patogenezi dentalnih resorptivnih lezija u mačaka. 